\title{
Penerapan model pembelajaran inquiry training dan model pembelajaran kooperatif tipe group investigation berbantuan laboratorium mini pada hasil belajar siswa kimia di SMA
}

\author{
I Kadek Cenik ${ }^{* a}$, Sonny Lumingkewas ${ }^{a}$, Meiske N. Mamuaja ${ }^{a}$ \\ a Universitas Negeri Manado, Tondano, 95618, Indonesia
}

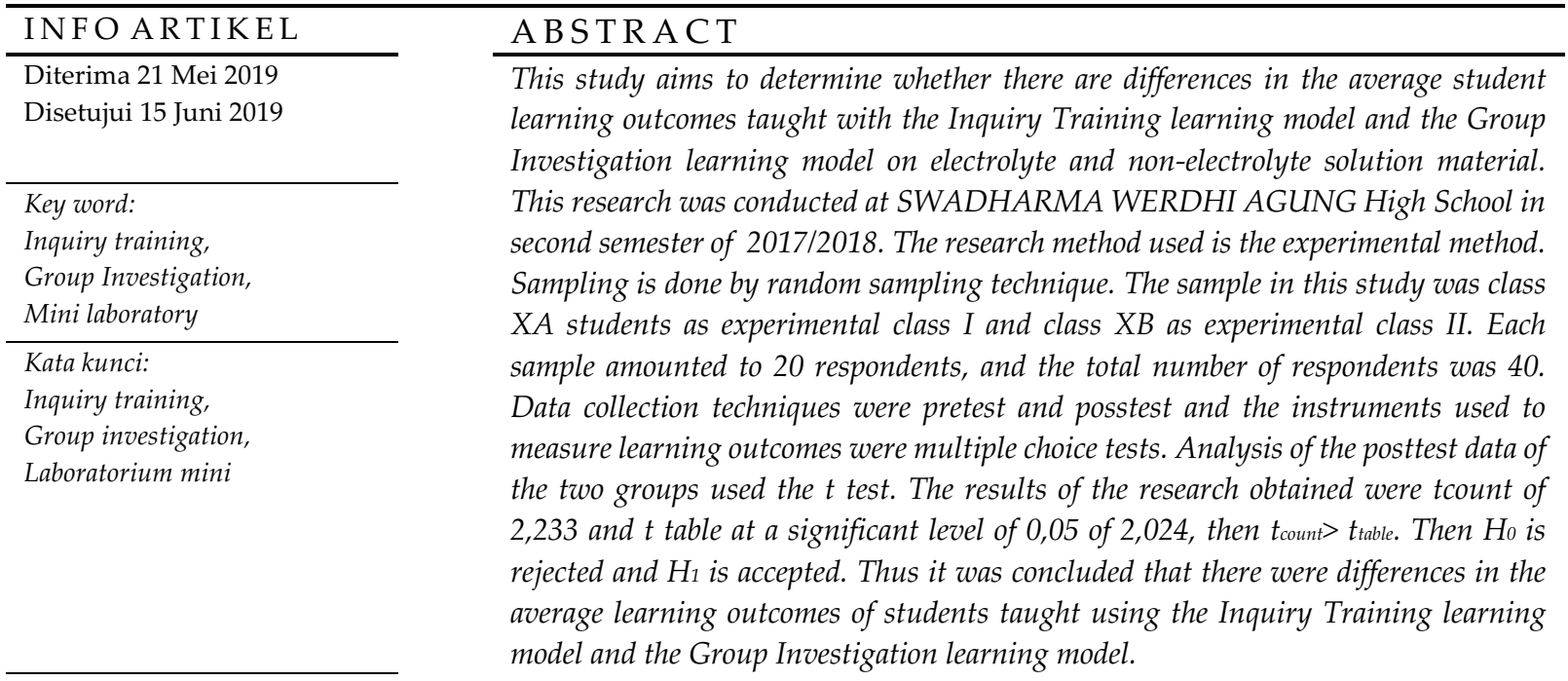

\section{ABSTRAK}

${ }^{*} e$-mail:

kadekcenik69@gmail.com

${ }^{*}$ Telp:

\begin{abstract}
Penelitian ini bertujuan untuk mengetahui apakah terdapat perbedaan ratarata hasil belajar siswa yang diajarkan dengan model pembelajaran Inquiry Training dan model pembelajaran Group Investigation pada materi larutan elektrolit dan non-elektrolit. Penelitian ini dilaksanakan di SMA SWADHARMA WERDHI AGUNG pada semester genap 2017/2018. Metode penelitian yang digunakan adalah metode eksperimen. Pengambilan sampel dilakukan dengan teknik random sampling. Sampel dalam penelitian ini adalah siswa kelas XA sebagai kelas ekperimen I dan kelas XB sebagai kelas eksperimen II. Masing-masing sampel berjumlah 20 responden, dan total jumlah responden ada 40 . Teknik pengumpulan data adalah pretest dan posstest serta instrument yang digunakan untuk mengukur hasil belajar merupakan tes pilihan ganda. Analisis data posttest kedua kelompok menggunakan uji t. Hasil penelitian yang diperoleh yaitu thitung sebesar 2,233 dan ttabel pada taraf signifikan 0,05 sebesar 2,024, maka thitung > tabel. Maka $H_{0}$ ditolak dan $H_{1}$ diterima. Dengan demikian disimpulkan bahwa terdapat perbedaan rata-rata hasil belajar siswa yang diajarkan menggunakan model pembelajaran Inquiry Training dan model pembelajaran Group Investigation.
\end{abstract}

\section{Pendahuluan}

Pendidikan merupakan salah satu aspek penting dalam pembangunan bangsa, karena itu hampir semua bangsa menempatkan pembangunan pendidikan sebagai prioritas utama dalam program pembangunan nasional. Sejalan dengan kemajuan-kemajuan di bidang ilmu pengetahuan dan teknologi, pendidikan di Indonesia terus mengalami perkembangan dari tahun ke tahun. Hal ini disertai dengan adanya 
upaya peningkatan kualitas pendidikan di Indonesia. Upaya tersebut diantara perbaikan kurikulum, pembaruan metode-metode dalam mengajar, pengadaan buku-buku pembelajaran di sekolah, dan perlengkapan-perlengkapan penunjang lain.

Kimia merupakan salah satu cabang sains/IPA yang berisi pengetahuan yang didasarkan pada fakta, dan hasil penelitian yang telah dilakukan oleh para ahli [1]. Kimia berkaitan langsung dalam kehidupan manusia terutama dalam kehidupan sehari-hari, akan tetapi tidak sedikit orang yang menganggap kimia sebagai ilmu yang kurang menarik. Hal ini disebabkan karena kimia erat hubungannya dengan ide-ide atau konsep-konsep abstrak yang membutuhkan penalaran ilmiah, sehingga belajar kimia merupakan kegiatan mental yang membutuhkan penalaran tinggi. Akibatnya proses pembelajaran tidak berjalan dengan baik dan menyebabkan siswa sulit untuk memahami pelajaran yang diberikan guru.

Guru memegang peran penting dalam pembelajar, oleh karena itu guru diharapkan mampu memiliki metode mengajar yang baik, dan mampu memilih metode pembelajaran yang tepat, sehingga peserta didik mampu mencapai kopetensi-kopetensi yang telah ditetapkan dalam pembelajaran yang dilakukan. Akan tetapi dari hasil observasi yang dilakukan di SMA Swadharma Werdhi Agung ditemukan bahwa metode pembelajaran yang diberikan oleh guru masih berpusat pada guru dan peran siswa hanya sebagai pendengar dan mencatat apa yang diberikan oleh guru. Akibatnya, peserta didik tidak tertarik untuk belajar, siswa sulit mengerti pada materi-materi tertentu dan proses pembelajaran yang berlangsung tidak efektif. Sejalan dengan hal tersebut menyebabkan hasil belajar siswa masih berada di bawah KKM yang di tentukan. Hal ini terlihat pada hasil belajar siswa pada mata pelajaran kimia di SMA Swadharma Werdhi Agung masih di bawah KKM. Dari data hasil ujian tengah semester kelas X tahun 2016/2017 didapatkan siswa yang memenuhi nilai KKM sekitar $42 \%$ dan sisanya masih dibawah KKM yang ditetapkan oleh sekolah tersebut yaitu 75 .

Usaha yang dapat dilakukan untuk memperbaikinya adalah dengan menggunakan metode dan model pembelajaran yang melibatkan siswa secara aktif sehingga siswa belajar dengan suasana yang menyenangkan. Metode pembelajaran kooperatif merupakan metode pembelajaran yang melibatkan siswa secara aktif dalam kelompok. Pembelajaran kooperatif adalah suatu pembelajaran dengan penekanan pada aspek sosial dan menggunakan kelompok-kelompok kecil yang terdiri dari $4-6$ orang siswa yang sederajat dalam kelompok yang heterogen [2]. Dalam pembelajaran kooperatif siswa saling berinteraksi, memunculkan strategi-strategi pemecahan masalah dalam kelompok dan menuntut tanggung jawab kelompok.

Model pembelajaran Inquiry Training dan Group Investigation adalah dua contoh dari sekian banyak model pembelajaran kooperatif. Model pembelajaran Inquiry Training adalah model pembelajran yang melibatkan kemampuan berfikir kritis pembelajar untuk menganalisis dan memecahkan persoalan secara sistematis. Dalam model ini siswa dihadapkan langsung pada permasalahan, mencari jawaban terhadap pertanyaan atau permasalahan yang di dapat dengan menganalisis masalah tersebut dan menemukan data-data yang mendukung jawaban dari masalah tersebut.

Sebaliknya model pembelajaran Group Investigation merupakan model pembelajaran yang melibatkan siswa dalam pelaksanaan investigasi. Pada model ini siswa diajak terlibat dalam pembelajaran sejak awal perencanaan, pemilihan topik, penentuan topik maupun dalam mempelajari topik tersebut dalam melakukan inversigasi. Selain itu, siswa juga dilibatkan langsung dalam menyiapkan dan menyajikan laporan hasil investigasi.

\section{Metode}

Penelitian ini dilaksanakan di SMA Swadharma Werdhi Agung pada semester genap tahun ajaran 2017/2018 pada materi larutan elektrolit dan nonelektrolit. Peneliti menggunakan model pembelajaran Inquiry Training dan model pembelajaran kooperatif tipe Group Investigation berbantuan laboratorium mini.

Desain penelitian ini menggunakan quasi eksperimental design yaitu Nonequivalent 
Control Group Design yang dapat dilihat pada Tabel 1 berikut:

Tabel 1. Desain Penelitian [3]

\begin{tabular}{ccc}
\hline $\mathrm{O}_{1}$ & $\mathrm{X}_{1}$ & $\mathrm{O}_{2}$ \\
\hline $\mathrm{O}_{3}$ & $\mathrm{X}_{2}$ & $\mathrm{O}_{4}$ \\
\hline
\end{tabular}

Keterangan :

$\mathrm{O}_{1}$ : pemberian tes awal (pretest) pada kelas eksperimen I

$\mathrm{O}_{3}$ : pemberian tes awal (pretest) pada kelas eksperimen II

$\mathrm{X}_{1}$ : pembelajaran menggunakan model kooperatif tipe Group Investigation

$\mathrm{X}_{2}$ : pembelajaran menggunakan model Inquiry Training

$\mathrm{O}_{2}$ : pemberian tes akhir (posttest) pada kelas eksperimen I

$\mathrm{O}_{4}$ : pemberian tes akhir (posttest) pada kelas eksperimen II

\section{Hasil Dan Pembahasan \\ Hasil Penelitian}

Data pada tabel 2 terlihat bahwa hasil statistik tes akhir (posttest) untuk kelas eksperimen I dengan menggunakan model pembelajaran Inquiry Training diperoleh jumlah skor total akhir $($ posttest $)=1680$ dengan rata-rata 84 , skor minimum 60 , dan skor maksimum 100 , standar deviasi 11,87 dan varians sebesar 141,05, sedangkan untuk kelas eksperimen II dengan model pembelajaran Group Investigation diperoleh jumlah skor total akhir (posttest) $=$ 1500 dengan rata-rata 75 , skor minimum 50 , dan skor maksimum 100, standar deviasi 13,57 dan varians sebesar 184,21. Dari hasil tersebut dapat dilihat bahwa kelas yang di ajar dengan model pembelajaran Inquiry Training mendapat nilai rata-rata lebih tinggi dari model pembelajaran Group Investigation.

Data pada tabel 3 tampak hasil uji normalitas data menggunakan uji Lilliefors dari data posttest kedua kelas eksperimen diperoleh untuk data kelas eksperimen I Lhitung $<$ Ltabel $(0,14$ $<0,19)$ dan pada kelas eksperimen II Lhitung < Ltabel $(0,15<0,19)$ maka kedua data kelas eksperimen disimpulkan berdistribusi normal.

Hasil analisis pengujian statistik uji homogenitas pada data hasil posttest dengan $S_{1}^{2}=141,05$ dan $S_{2}^{2}=184,21$ dengan taraf nyata $\mathrm{a}=0,05$ diperoleh nilai Fhitung $=0,76$ dengan $F_{\text {tabel }}=3,245$. Hal ini menunjukkan bahwa Fhitung $<F_{\text {tabel }}$ sehingga, dapat disimpulkan bahwa varians dari kelas eksperimen I dan kelas eksperimen II adalah homogen dan layak dijadikan sampel penelitian
Tabel 2. Data hasil posttest kelas eksperimen I dan eksperimen II

\begin{tabular}{cccc}
\hline No & Statistik & \multicolumn{2}{c}{$\begin{array}{c}\text { Data Hasil Posttest } \\
\text { Kelas Eksperimen I dan } \\
\text { Eksperimen II }\end{array}$} \\
\cline { 3 - 4 } & & $\begin{array}{c}\text { Model } \\
\text { Inquiry } \\
\text { Training }\end{array}$ & $\begin{array}{c}\text { Model } \\
\text { Group } \\
\text { Investigation }\end{array}$ \\
\hline 1 & Jumlah $\left(\sum\right)$ & 1680 & 1500 \\
\hline 2 & Rata-rata & 84 & 75 \\
\hline \multirow{3}{*}{$\begin{array}{c}\text { Skor } \\
\text { Minimum }\end{array}$} & 60 & 50 \\
\hline \multirow{3}{*}{$\begin{array}{c}\text { Skor } \\
\text { maksimum }\end{array}$} & 100 & 100 \\
\hline \multirow{3}{*}{$\begin{array}{c}\text { Standar } \\
\text { Deviasi (SD) }\end{array}$} & 11.87 & 13.57 \\
\hline 6 & Varians & 141.05 & 184.21 \\
\hline \multicolumn{3}{c}{}
\end{tabular}

Tabel 3. Ringkasan Data hasil Uji Normalitas

\begin{tabular}{ccccc}
\hline Kelas & $\mathrm{N}$ & Lhitung & $\begin{array}{c}\text { Ltabel } \\
(\alpha=0,05)\end{array}$ & Kesimpulan \\
\hline $\begin{array}{c}\text { Eksperimen } \\
\text { I }\end{array}$ & 20 & 0.14 & 0.19 & NORMAL \\
\hline $\begin{array}{c}\text { Eksperimen } \\
\text { II }\end{array}$ & 20 & 0.15 & 0.19 & NORMAL \\
\hline
\end{tabular}

\section{Pembahasan}

Penelitian ini dilaksanakan pada kelas XA dan kelas XB di SMA Swadharma Werdhi Agung tahun ajaran 2016/2017. Tujuan dari penelitian ini yaitu untuk mengetahui perbedaan hasil belajar antara kelas yang diajar menggunakan model pembelajaran Inquiry Training dan model pembelajaran Group Investigation pada materi larutan elektrolit dan non elektrolit dengan berbantuan laboratorium mini. Penggunaan laboratorium mini dalam penelitian ini bertujuan sebagai pengantar untuk membantu siswa dalam memahami konsep-konsep yang bersifat abstrak dan selain itu juga membantu peneliti dalam mengaitkan dengan materi yang akan diberikan. Sebelum proses pembelajaran materi larutan elektrolit dan nonelektrolit diberikan, kedua kelas diberikan pretest. Pretest ini diberikan dengan tujuan untuk mengukur kemampuan awal siswa mengenai pembelajaran yang akan diberikan. Akan tetapi, pemberian pretest juga memberikan kekurangan yaitu adanya jawaban tebakan siswa karena siswa belum menerima materi dan harus mengerjakan soal pretest yang berisi materi yang belum diketahui. 
Berdasarkan pretest yang di berikan, diperoleh hasil rata-rata pretest kelas eksprimen I yaitu 45,5 sedangkan kelas eksperimen II yaitu 30. Selanjutnya kedua kelas di berikan perlakuan dimana kelas eksperimen I di berikan model pembelajaran Inquiry Training dan kelas eksperimen II diberikan model pembelajaran Group Investigation. Pemberian posttest dilakukan setelah kedua kelas eksperimen diberikan perlakuan model pembelejaran yang telah ditentukan. Pada hasil analisis posttes diketahui data berdistribusi normal berdasarkan uji normalitas liliefors dan homogen berdasarkan uji homogenitas menggunakan uji F. Uji normalitas dan homogenitas merupakan suatu syarat untuk melakukan uji hipotesis dengan menggunakan uji dua rerata. Uji dua rerata atau uji $t$ dapat dilakukan jika data berdistribusi normal dan homogan.

Data pada tabel 4 terlihat bahwa kelas yang diajar menggunakan model pembelajaran Inquiry Training mendapat nilai rata-rata lebih tinggi dibandingkan kelas yang diajar dengen model pembelajaran Group Investigation. Setelah dilakukan pengujian hipotesis menggunakan $\mathrm{t}$ diperoleh thitung $=2,23$. Pada taraf signifikan 0,05 diperoleh tabel $=2,02$ sehingga di dapatkan thitung $>$ tabel, maka $\mathrm{H}_{0}$ ditolak dan terima $\mathrm{H}_{1}$ yang artinya terdapat perbedaan rata-rata hasil belajar siswa yang diajar dengan model pembelajaran Inquiry Training dan model pembelajaran Group Investigation. Selain itu perbedaan hasil belajar tersebut dapat dilihat dari hasil analisis gain score pada masingmasing kelas eksperimen. Analisis gain score adalah suatu cara analisis data dengan mencari selisih dari nilai rata-rata pretest dan postest setelah semua materi diberikan kepada siswa. Data tersebut dapat dilihat pada tabel berikut:

Tabel 4. Mean gain score kelas eksperimen I dan eksperimen II

\begin{tabular}{cccc}
\hline KELAS & $\begin{array}{c}\text { Mean } \\
\text { Pretest }\end{array}$ & $\begin{array}{c}\text { Mean } \\
\text { Posttest }\end{array}$ & $\begin{array}{c}\text { Mean } \\
\text { Gain } \\
\text { Score }\end{array}$ \\
\hline $\begin{array}{c}\text { EKSPERIMEN } \\
\text { I }\end{array}$ & 45,5 & 84 & 38,5 \\
\hline $\begin{array}{c}\text { EKSPERIMEN } \\
\text { II }\end{array}$ & 35 & 75 & 40 \\
\hline
\end{tabular}

Berdasarkan hasil analisis gain score pada masing-masing kelas eksperimen I dan kelas eksperimen II, diketahui bahwa mean gain score pada kelas eksperimen I yaitu 38,5 lebih kecil dari mean gain score pada kelas eksperimen II yaitu 40. Dengan demikian, kelas yang diajar dengan model pembelajaran Inquiry Training lebih unggul dibandingkan dengan model pembelajaran Group Investigation terhadap hasil belajar siswa kelas X SMA Swadharma Werdhi Agung pada materi larutan elektrolit dan nonelektrolit.

Perbedaan hasil belajar ini disebabkan oleh beberapa hal yaitu: Pertama, kemampuan awal. Kemampuan awal merupakan pengetahuan atau keterampilan yang telah dimiliki peserta didik sebelum ia mengikuti mata pelajaran yang akan diberikan [4]. Dengan kemampuan ini peserta didik dapat mempelajari materi yang akan di belajarkan guru sebaliknya tanpa kemampuan ini peserta didik akan mengalami kesulitan mempelajari materi yang diberikan. Oleh karena itu kemampuan awal menjadi bagian penting dalam keberhasilan siswa dalam memahami materi yang diberikan guru. Berdasarkan hasil pretest kelas yang diajar dengan menggunakan model pembelajaran Inquiry Training memiliki kemampuan awal yang lebih tinggi dibandingkan dengan kelas yang diajar dengan model pembelajaran Group Investigation atau dengan kata lain siswa pada kelas Inquiry Training memiliki kemampuan lebih tinggi dibandingkan kelas Group Investigation. Dengan demikian, kemampuan awal siswa sangat mempengaruhi pemahaman siswa dan hasil belajar siswa sehingga, semakin tinggi kemampuan awal siswa maka semakin tinggi kemungkinan keberhasilan siswa dalam memahami materi yang diberikan.

Kedua, bimbingan guru dalam belajar. Bimbingan belajar merupakan kegiatan bimbingan yang bertujuan agar siswa mampu mencapai keberhasilan dalam belajar secara optimal [5]. Bimbingan belajar juga merupakan suatu bentuk kegiatan dalam proses belajar yang dilakukan oleh seseorang yang memiliki kemampuan lebih dalam banyak hal untuk diberikan kepada orang lain yang mana bertujuan agar orang lain dapat menemukan pengetahuan baru dan dapat diterapkan dalam kehidupannya [6]. Dalam penerapannya model 
pembelajaran Inquiry Training dan model pembelajaran Group Investigation memiliki perbedaan langkah-langkah dalam penerapannya yaitu terdapat perbedaan dalam bimbingan belajar yang diberikan. Adanya bimbingan peneliti pada kelas yang diajar dengan model pembelajaran Inquiry Training dalam merumuskan hipotesis, mengumpulkan data, dan menyimpulkan data yang diperoleh sedangkan pada kelas yang diajar dengan model pembelajaran Group Investigation bimbingan peneliti hanya memberikan sedikit bimbingan sehingga siswa harus lebih mandiri dalam melaksanakan investigasi dan memecahkan masalah yang mereka hadapi. Bimbingan yang diberikan peneliti menyebabkan tingkat keberhasilan siswa dalam memahami materi lebih baik dan berdapak pada hasil belajar siswa, apalagi mata pelajaran kimia baru mereka dapatkan pada waktu SMA sehingga diperlukan bimbingan agar materi yang dipelajari lebih terarah.

Ketiga, perbedaan sub topik yang didapat berdasarkan langkah-langkah pembelajaran. Pada penerapan langkah-langkah model pembelajaran Inquiry Training setiap kelompok mendapat sub topik yang sama sedangkan pada model pembelajaran Group Investigation setiap kelompok mendapat sub topik yang berbeda sehingga, berpengaruh pada pemahaman siswa. Pemahaman sub topik siswa pada kelas yang diajar model pembelajaran Inquiry Training lebih baik dari pada kelas yang diajar model pembelajaran Group investigation. Hal ini disebabkan karena pada model Inquiry Training siswa dalam kelompok mendapatkan semua sub topik yang sama, sehingga mereka lebih menguasai semua sub topik pada materi larutan elektrolit dan non elektrolit. Sedangkan, pada model Group Investigation siswa pada dalam kelompok mendapatkan sub topik yang berbeda, sehingga menyebabkan siswa lebih menguasai sub topik yang didapat pada materi larutan elektrolit.

\section{Ucapan terimakasih}

Disampaikan banyak terima kasih kepada seluruh dosen di Jurusan Kimia Fakultas Matematika dan Ilmu Pengetahuan Alam Universitas Negeri Manado dan juga SMA
Swadharma Werdhi Agung yang berperan penting dalam pelaksanaan penelitian ini.

\section{Kesimpulan}

Penelitian yang dilakukan di SMA Swadharma Werdhi Agung menunjukkan terdapat perbedaan hasil belajar siswa yang diajar menggunakan model pembelajaran Inquiry Training dan model pembelajaran Group Investigation.

\section{Daftar Pustaka}

1. Budi, L., Yamtinah, S dan Redjeki, T. Pengaruh Metode Pembelajaran Group Investigation (Gi) dan Minat Terhadap Prestasi Belajar Siswa Pada Pokok Bahasan Struktur Atom Dan Sistem Periodik Kelas XI SMAN 6 Surakarta Tahun Pelajaran 2012/2013. Jurnal Pendidikan Kimia. 2013, Vol 2 (3) : 11.

2. Ratnaya. Implementasi Pembelajaran Kooperatif Tipe Group Investigation Untuk Meningkatkan Aktivitas Dan Hasil Belajar Matematika. Jurnal Pendidikan Dan Pengajaran. 2013, Vol 46 (2) : 127.

3. Sugiyono. Statistika untuk Penelitian. Alfabeta : Bandung, Indonesia, 2013; ISBN.

4. Hasrida. Pengaruh Model Pembelajaran Dan Kemampuan Awal Terhadap Pemahaman Konsep Dan Motivasi Belajar Peserta Didik Kelas X SMA Negeri 1 Maniangpajo (Studi Pada Materi Pokok Larutan Elektroit dan Nonelektrolit). Tesis. Makassar, Universitas Negeri Makasar, 2017.

5. Mulyaningsih. Pengaruh Bimbingan Belajar Orang Tua Terhadap Prilaku Disiplin dan Hasil Belajar Matematika Siswa Kelas V SD Se-Gugus Diponegoro Bansari Tumanggung. Skripsi, Semarang, Universitas Negeri Semarang, 2016.

6. Aisyah, S. Perkembangan Peserta Didik $\mathcal{E}$ Bimbingan Belajar. Budi Utama : Yogyakarta, Indonesia, 2015. ISBN. 